\title{
A Different Approach to Cancer and Drug Resistance in Cancer: Parasites ${ }^{+}$
}

\author{
Armağan Caner ${ }^{1, *}$, Ülffet Çetinkaya ${ }^{2}$, Meryem Şentürk ${ }^{3}$, Arzuv Charyyeva ${ }^{4}$ and Meryem Eren ${ }^{3}$ \\ 1 Department of Biophysics, Faculty of Medicine, Erciyes University, 38280 Kayseri, Turkey \\ 2 Halil Bayraktar Vocational School of Health Services, Erciyes University, 38280 Kayseri, Turkey; \\ drulfetcetinkaya@gmail.com \\ 3 Department of Biochemistry, Faculty of Veterinary Medicine, Erciyes University, 38280 Kayseri, Turkey; \\ meryemgltkn@hotmail.com (M.Ş.); meren@erciyes.edu.tr (M.E.) \\ 4 Life Science Research Centre, Faculty of Science, Ostrava University, 70103 Ostrava, Czech Republic; \\ arzuvc@gmail.com \\ * Correspondence: armagan.caner@gmail.com; Tel.: +90-542-385-5867 \\ + Presented at the 3rd International conference on Natural Products for Cancer Prevention and Therapy, \\ Kayseri, Turkey, 18-20 December 2019.
}

Published: 26 December 2019

\begin{abstract}
Encephalitozoon intestinalis (E. intestinalis) is a parasite that causes opportunistic infections that can cause death in immune compromised patients. The aim of this study was to determine the effect of parasite on genes involved in host cell apoptosis. The CaCo cells were infected with $E$. intestinalis 50506 (ATCC) strain. Apoptosis was induced in both control and parasite-infected groups after infection. RNA isolation and cDNA extraction were then performed. Changes in the expression of genes involved in apoptotic pathways were evaluated quantitatively (qPCR) by Real-Time PCR. The obtained data were analyzed by $2^{-\Delta \Delta C t}$ method. E. intestinalis inhibits the CASP6, DR4, DR5, DCR2 genes that regulate the transcription of the genes known as the death gene of cells in CaCo cells. TP53 regulates the transcription of certain genes involved in cell death. DR4, DR5 and DCR2 are inhibited by the introduction of E. intestinalis into the cell. Caspase 6 is one of the caspases that induces apoptosis. As can be seen from the activation of these genes, E. intestinalis inhibits transcription genes in the pro-apoptotic pathway of the cell. We think that this parasite, which is commonly found in cancer patients, should be investigated for the effect of drug resistance in cancer treatment. This study was supported by Erciyes University. Project ID: TCD-2016-7042.
\end{abstract}

Keywords: parasite; Encephalitozoon intestinalis; cancer; anticancer drug resistance

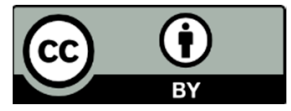

(C) 2019 by the authors. Licensee MDPI, Basel, Switzerland. This article is an open access article distributed under the terms and conditions of the Creative Commons Attribution (CC BY) license (http://creativecommons.org/licenses/by/4.0/). 